\title{
Growth and Yield Response of Mungbean as Influenced by Sulphur and Boron Application
}

\author{
Sri Laxmi ${ }^{*}$, Ruby Patel $^{2}$, Sonam Singh ${ }^{1}$, Babulal Choudhary ${ }^{1}$, \\ Rajendra Gadhwal ${ }^{1}$, R. Meena ${ }^{2}$ and Y. V. Singh ${ }^{1}$ \\ ${ }^{1}$ Department of Soil Science \& Agricultural Chemistry, Banaras Hindu University, \\ Varanasi-221005, India \\ ${ }^{2}$ Department of Agricultural chemistry \& Soil Science, Bidhan Chandra Krishi \\ Viswavidyalaya Mohanpur, West Bengal, India \\ *Corresponding author
}

\section{A B S T R A C T}

\begin{tabular}{|l|}
\hline Key w o r d s \\
$\begin{array}{l}\text { Sulphur, boron, } \\
\text { test crop }\end{array}$ \\
\hline Article Info \\
\hline $\begin{array}{l}\text { Accepted: } \\
\text { 22 February } 2020 \\
\text { Available Online: } \\
\text { 10 March } 2020\end{array}$ \\
\hline
\end{tabular}

A pot experiment was conducted at Dept of soil Science and Agricultural Chemistry, Banaras Hindu University during the period from July 2017 to October 2017 to investigate the effect of sulphur $\left(0,10,20\right.$ and $\left.30 \mathrm{~kg} \mathrm{ha}^{-1}\right)$ and three levels of boron $\left(0,1\right.$ and $\left.2 \mathrm{~kg} \mathrm{ha}^{-1}\right)$ on growth and yield of mungbean as test crop. The experiment was laid out in factorial CRD with 12 treatments having three replications The results indicated that the crop responded significantly to sulphur and boron in respect of growth and yield such as plant height, number of branches plant ${ }^{-1}$, pods plant ${ }^{-1}$, podlength, number of seeds pod-1, test weight, seed yield, straw yield. In the combination of sulphur and boron, all the parameters were significant by influence. Maximum seed yield was recorded in treatment combination of $30 \mathrm{~kg} \mathrm{~S} \mathrm{ha}^{-1}$ and $2 \mathrm{~kg} \mathrm{~B} \mathrm{ha}^{-1}$.

\section{Introduction}

The growth of agriculture in India over last few decades has helped the country in achieving food security at national level. The next big challenge faced by the country in particular is to sustain this growth and achieve nutritional security as well. Producing sustainably is therefore becoming central in agriculture and food systems. Legume crops could play an important role in this context by delivering multiple services in line with sustainability principles. Green gramis one of the most important legume crops grown in India.

Besides being a rich source of protein, they also maintain soil fertility through biological nitrogen fixation in soil and thus play a vital role in maintaining sustainability.In spite of 
having the largest area under mungbean in the country its productivity is not satisfactory which yet to see a major breakthrough low productivity of mungbean is due to abiotic and biotic factors. Amongst them, imbalance use of fertilizers is one of the most important factors. Sulphur is an essential plant nutrient for higher pulse production and has been recognized as fourth major essential plant nutrient because of its widespread deficiency in many crops (Singh 2001).

Its deficiency is posing threats in achieving potential yield of pulses and other crops not only in marginal lands but also in fertile soils (Pasricha and Aulakh 1996: Singh et al., 1998).It is an integral part of sulphur containing amino acids cystine, cystein and methionine. Besides this it involves in various metabolic and enzymatic process including photosynthesis, respiration and legume rhizobium symbiotic nitrogen fixation (Rao et al., 2001).

The micronutrient especially Boron plays an important role in plant nutrition and recognized as major yield limiting factor in pulses (Ali et al., 2004). It helps in chlorophyll synthesis as well as involved in carbohydrates metabolism. The most important role of boron is to activate the germination of pollen, accelerates the growth of pollen tube and increases the number of flowers and fruits formation.So, there is an ample scope of increasing the yield of mungbean per unit area by using balanced fertilization including sulphur and boron. Therefore, the experiment was conducted to study the optimum doses of sulphur and boron on growth and yield of mungbean.

\section{Materials and Methods}

The experiment was conducted at the Dept of soil Science and Agricultural Chemistry, Institute of Agricultural Sciences, Banaras
Hindu University Varanasi, UttarPradesh, India during the period from July 2017 to October 2017 (Kharif). Mungbean variety HUM-16 was used as a test crop. The experimental soil developed on Gangetic alluvial have predominance of illite, quartz and feldspar minerals under Inceptisol soil order.

The experimental site is located at25.18, North latitude and 80.36, East latitude and at an altitude of $80.71 \mathrm{~m}$ above mean sea level in the Gangetic plain of Eastern Uttar Pradesh. The experiment was laid out in a factorial CRD consisting of 12 treatment combinations replicated thrice with four levels of sulfur $(0,10,20$ and $30 \mathrm{~kg}$ ha-1) and three levels of boron (0,1 and $2 \mathrm{~kg}$ ha- 1$)$ viz., T1-(S0B0) Control, T2- (S1B0) $10 \mathrm{~kg} \mathrm{~S}$ ha-1 + $0 \mathrm{~kg}$ B ha-1,T3- (S2B0) $20 \mathrm{~kg} \mathrm{~S}$ ha-1 + $0 \mathrm{~kg}$ B ha-1,T4- (S3B0) $30 \mathrm{kgS}$ ha-1 + $0 \mathrm{~kg}$ B ha1, T5- (S0B1) $0 \mathrm{~kg} \mathrm{~S}$ ha-1 +1 kg Bha-1, T6(S0B2) $0 \mathrm{~kg} \mathrm{~S}$ ha-1 + $2 \mathrm{~kg} \mathrm{~B}$ ha-1, T7 (S3B1)30 kg S ha-1 + $1.0 \mathrm{~kg} \mathrm{~B} \mathrm{ha-1,} \mathrm{T8-}$ (S3B2) $30 \mathrm{~kg} \mathrm{~S}$ ha-1 +2.0 kg B ha-1, T9(S1B1) $10 \mathrm{~kg} \mathrm{~S}$ ha-1 + $1.0 \mathrm{~kg}$ B ha-1,T10(S1B2) $10 \mathrm{~kg} \mathrm{~S}$ ha-1 + $2 \mathrm{~kg} \mathrm{~B}$ ha-1, T11(S2B1) 20kg S ha-1 + $1 \mathrm{~kg}$ B ha-1 and T12(S2B2) $20 \mathrm{~kg} \mathrm{~S}$ ha-1+ 2 kg B ha-1.

Each treatment received an equal amount of nitrogen, phosphorus and potassium except control applied basally through urea, diammonium phosphate and muriate of potash, respectively. Sulphur was applied in the form of gypsum and boron was applied in the form of borax. Seeds were sown in each polythene lined $10 \mathrm{~kg}$ earther pot.

Data on plant height and number of branches per plant, SPAD value, no. of pods per plant, no. of seeds per pod test weight, seed yield and straw yield were recorded from each pot. The data were statistically analysed by standard method (Panse and Sukhatme1967).

Results and Discussion 
Plant height was significantly influenced due to the increasing levels of Sulphur and its combination with boron at 15 and 45 days after sowing. The highest plant height (20.967) at 15 DAS was associated with Sulphur @ 30kg/ha (S3) closely followed by Sulphur @ 20kg/ha (S2). However, both were significantly superior to other treatments and control in respect of plant height. Effect of boron on plant height can also be understood from the table 4.3. Its effect at 15 DAS was found significant, highest in B1 (21.425) followed by B0 (21.342).

At 30 DAS boron effect on plant height is non-significant whereas at 45 DAS its effect is again found significant, maximum in B0 (42.158) and minimum in B2 (41.150). The interaction effect between Sulphur and boron in respect of plant height was found significant at 15, 30 and 45 DAS. Plant height at $30 \mathrm{~kg} \mathrm{~S} /$ ha was significantly higher over lower doses of Sulphur (Table 4.3). It might be due to favourable effect of Sulphur on root growth and development which increased the uptake of nutrients resulted in increased plant height. The increase in plant height of mungbean due to Sulphur application has also been reported by Shivran et al., (1996) Ramamorthy et al., (1997). Srinivasan and Sankaran (2001), Singh et al., (2004) and Singh et al., (2005). As the crop matures there is increase in no. of branches however initially no. of branches increases rapidly but 30 DAS there is gradual increase in no. of branches/plant. No. of branches at 45 DAS was found maximum in $\mathrm{S} 2$ (5.50) which is at par with S3 (5.389).

Number of branches increases with increasing Sulphur levels, it might be due to role of Sulphur in regulating metabolic and enzymatic process in plants as stated by Rao et al., (2001). Similar results have also been reported by Bhadoria (1997), Sharma et al., (2003) and Singh et al., (2003). Sulphur @ 30 $\mathrm{kg} / \mathrm{ha}(\mathrm{S} 3)$ resulted in significant increase in Seed yield (12.171 g/pot) closely followed by Sulphur@10 kg/ha (11.471 g/pot). However, both brought about significant improvement in Seed yield when compared to other levels of Sulphur and control.

Table.1 Effect of Sulphur and boron levels on plant height at different stage of Mungbean

\begin{tabular}{|c|c|c|c|}
\hline \multirow[t]{2}{*}{ Treatments } & \multicolumn{3}{|c|}{ Plant height (cm) } \\
\hline & 15DAS & 30DAS & 45DAS \\
\hline \multicolumn{4}{|c|}{ Sulphur levels(Kg/ha) } \\
\hline S0 & 20.389 & 30.489 & 40.733 \\
\hline S1 & 20.589 & 30.656 & 41.30 \\
\hline $\mathbf{S 2}$ & 20.600 & 32.144 & 43.200 \\
\hline S3 & 20.967 & 30.622 & 41.389 \\
\hline $\operatorname{Sem}( \pm)$ & 0.059 & 0.405 & 0.273 \\
\hline $\mathrm{CD}(\mathrm{P}=\mathbf{0 . 0 5})$ & 0.173 & 1.190 & 0.801 \\
\hline \multicolumn{4}{|c|}{ Boron levels (Kg/ha) } \\
\hline B0 & 21.342 & 29.500 & 42.158 \\
\hline B1 & 21.425 & 29.767 & 41.675 \\
\hline B2 & 20.642 & 29.400 & 41.150 \\
\hline $\operatorname{Sem}( \pm)$ & 0.051 & 0.351 & 0.236 \\
\hline $\mathrm{CD}(\mathrm{P}=\mathbf{0 . 0 5})$ & 0.149 & NS & 0.694 \\
\hline
\end{tabular}


Table.2 Interaction effect of Sulphur and boron levels on plant height (cm) at different stages of Mungbean

\begin{tabular}{|c|c|c|c|c|c|c|c|c|c|}
\hline \multirow[b]{2}{*}{$\mathbf{S} \times \mathbf{B}$} & \multicolumn{3}{|c|}{ Plant height (15DAS) } & \multicolumn{3}{|c|}{ Plant height (30DAS) } & \multicolumn{3}{|c|}{ Plant height (45DAS) } \\
\hline & B0 & B1 & B2 & B0 & B1 & B2 & B0 & B1 & B2 \\
\hline S0 & 20.133 & 20.200 & 20.067 & 29.500 & 29.76 & 29.400 & 40.067 & 40.167 & 40.367 \\
\hline S1 & 20.333 & 20.367 & 20.400 & 31.000 & 30.83 & 30.760 & 40.633 & 40.700 & 40.700 \\
\hline $\mathbf{S 2}$ & 20.700 & 21.067 & 21.433 & 30.967 & 30.100 & 31.000 & 41.500 & 41.430 & 42.033 \\
\hline S3 & 21.500 & 23.33 & 24.100 & 32.8 & 32.600 & 33.000 & 43.367 & 44.500 & 44.467 \\
\hline $\operatorname{Sem}( \pm)$ & \multicolumn{3}{|c|}{0.102} & \multicolumn{3}{|c|}{0.702} & \multicolumn{3}{|c|}{24.1} \\
\hline $\mathrm{CD}(\mathrm{P}=\mathbf{0 . 0 5})$ & \multicolumn{3}{|c|}{0.299} & \multicolumn{3}{|c|}{2.061} & \multicolumn{3}{|c|}{1.387} \\
\hline
\end{tabular}

Table.3 Effect of Sulphur and boron levels on no. of branches/plant at different stages of mungbean

\begin{tabular}{|l|c|c|c|}
\hline \multirow{2}{*}{ Treatments } & \multicolumn{3}{|c|}{ No. of branches/plant } \\
\hline Sulphur levels(Kg/ha) & 15DAS & 30DAS & 45DAS \\
\hline S0 & & & \\
\hline S1 & 1.000 & 4.056 & 5.056 \\
\hline S2 & 1.056 & 4.111 & 5.167 \\
\hline S3 & 1.278 & 4.333 & 5.500 \\
\hline Sem $(\mathbf{\pm})$ & 1.000 & 4.222 & 5.389 \\
\hline CD $(\mathbf{P = 0 . 0 5 )}$ & 0.062 & 0.111 & 0.096 \\
\hline Boron levels (Kg/ha) & 0.182 & NS & 0.283 \\
\hline B0 & & & \\
\hline B1 & 1.125 & 4.208 & 5.458 \\
\hline B2 & 1.125 & 4.208 & 5.250 \\
\hline Sem $( \pm)$ & 1.000 & 4.125 & 5.125 \\
\hline CD $(\mathbf{P = 0 . 0 5 )}$ & 0.054 & 0.096 & 0.083 \\
\hline & NS & NS & 0.245 \\
\hline
\end{tabular}

Table.4 Interaction effect of Sulphur and boron levels on no. of branches/plant at different stages of Mung bean

\begin{tabular}{|c|c|c|c|c|c|c|c|c|c|}
\hline \multirow[t]{2}{*}{$S \times B$} & \multicolumn{3}{|c|}{$\begin{array}{l}\text { No. of branches/plant } \\
\text { (15DAS) }\end{array}$} & \multicolumn{3}{|c|}{$\begin{array}{l}\text { No. of branches/plant } \\
\text { (30DAS) }\end{array}$} & \multicolumn{3}{|c|}{$\begin{array}{c}\text { No. of branches/plant } \\
\text { (45DAS) }\end{array}$} \\
\hline & BO & B1 & B2 & B0 & B1 & B2 & B0 & B1 & B2 \\
\hline So & 1.000 & 1.000 & 1.000 & 4.000 & 4.000 & 4.000 & 5.000 & 5.000 & 5.000 \\
\hline S1 & 1.000 & 1.000 & 1.000 & 4.000 & 4.000 & 4.167 & 5.000 & 5.000 & 5.833 \\
\hline S2 & 1.000 & 1.000 & 1.000 & 4.167 & 4.167 & 4.333 & 5.167 & 5.000 & 5.333 \\
\hline $\mathbf{S 3}$ & 1.167 & 1.33 & 1.500 & 4.333 & 4.333 & 4.677 & 5.500 & 5.500 & 6.000 \\
\hline Sem $( \pm)$ & \multicolumn{3}{|c|}{0.108} & \multicolumn{3}{|c|}{0.192} & \multicolumn{3}{|c|}{0.167} \\
\hline $\mathrm{CD}(\mathrm{P}=\mathbf{0 . 0 5})$ & \multicolumn{3}{|c|}{ NS } & \multicolumn{3}{|c|}{ NS } & \multicolumn{3}{|c|}{0.489} \\
\hline
\end{tabular}


Table.5 Effect of Sulphur and boron levels on Seed and straw yield of mungbean

\begin{tabular}{|l|c|c|}
\hline Treatments & Seed Yield (g/pot) & Straw yield(g/pot) \\
\hline Sulphur levels(Kg/ha) & & \\
\hline S0 & 10.865 & 6.580 \\
\hline S1 & 11.471 & 6.616 \\
\hline S2 & 11.280 & 7.414 \\
\hline S3 & 12.171 & 6.770 \\
\hline Sem $(\mathbf{\pm})$ & 0.206 & 0.057 \\
\hline CD $(\mathbf{P}=\mathbf{0 . 0 5})$ & 0.604 & 0.166 \\
\hline Boron levels (Kg/ha) & & \\
\hline B0 & 11.289 & 6.933 \\
\hline B1 & 11.583 & 6.928 \\
\hline B2 & 11.428 & 6.673 \\
\hline Sem $( \pm)$ & 0.178 & 0.049 \\
\hline CD $(\mathbf{P}=\mathbf{0 . 0 5})$ & NS & 0.144 \\
\hline
\end{tabular}

Table.6 Interaction effect of Sulphur and boron levels on seed and straw yield of mungbean

\begin{tabular}{|l|c|c|c|c|c|c|}
\hline S x B & \multicolumn{3}{|c|}{ Seed yield(g/pot) } & \multicolumn{3}{c|}{ Straw Yield (g/pot) } \\
\hline S0 & B0 & B1 & B2 & B0 & B1 & B2 \\
\hline S1 & 10.513 & 10.533 & 10.767 & 6.496 & 6.410 & 6.467 \\
\hline S2 & 11.100 & 11.193 & 11.403 & 6.626 & 6.716 & 6.730 \\
\hline S3 & 11.100 & 11.776 & 11.683 & 6.616 & 6.686 & 6.893 \\
\hline Sem $(\mathbf{\pm})$ & 12.160 & 12.440 & 12.960 & 6.970 & 7.536 & 7.990 \\
\hline CD(P=0.05) & & & 0.356 & & 0.098 & \\
\hline
\end{tabular}

It is apparent from the data that maximum straw yield was registered under S2 (7.414 $\mathrm{g} / \mathrm{pot}$ ) which was significantly superior to the straw yield obtained under S3 (6.77 g/pot). Higher straw yield per pot with increased levels of Sulphur seem to be supported by number of branches per plant (Table 4.5) and plant height (Table 4.3) which is also increased with increasing rates of Sulphur upto almost same level.

The interaction effect of Sulphur and boron levels was found significant for straw yield. The possible reasons for increase in seed and straw yield due to Sulphur application at higher rate are in accordance to those of Joseph et al., (1995), Bhadoria et al.,
(1997),Singh et al., (1998), Chanda et al., (2002), Sharma et al., (2003) Singh et al., (2005) and Ali (2010).

All these research workers observed significant increase in seed and or straw yields with increased application of Sulphur from 20 to $40 \mathrm{~kg} / \mathrm{ha}$. However, in current research it is found that application of $30 \mathrm{~kg}$ $\mathrm{S} / \mathrm{ha}$ recorded maximum Seed yield followed by $20 \mathrm{~kg} \mathrm{~S} / \mathrm{ha}$ and they were significantly superior to $0,10 \mathrm{~kg} / \mathrm{ha}$ but remained at par among each other. Combined application of Sulphur and boron were significantly increase the Seed and straw yield of mungbean as the combinations significantly increase the plant height (45 DAS), number of branches/plant 
(45 DAS), number of pods/plant and number of seeds/pod. It may be explained that the 30 $\mathrm{kg}$ S/ha and $2 \mathrm{~kg} \mathrm{~B} / \mathrm{ha}$ had beneficial effect on it by improving metabolic enzymatic process in the plant and encourages vegetative growth of plant (formation and enlargement of leaves, increase internodes and ancillary buds). Thus increased growth characters attributed to registered highest Seed and straw yield at same combination of Sulphur and boron.

\section{Acknowledgement}

Authors greatly acknowledge to the Head, Department of Soil Science and Agricultural Chemistry, Institute of Agricultural Sciences, BHU, Varanasi for providing all necessary facilities to carry out research work. Authors are also thankful to Stuti Krishna, Ph.D scholar Navsari agriculture university for helping in statistical analysis of the data.

\section{References}

Ali, J. (2010) Status of available Sulphur and zinc in soils and response of mustard to Sulphur. Annals of Plant and Soil Research. 12: 77-78.

Ali, M. Singh, K.K. and Soad, A.A. 2004. Balance fertilization for nutritional quality in pulses. Fertilizer News.49(4): 47-56.

Aulakh, M.S. and N.S. Pasricha. 1996. Nitrogen and phosphorus requirement and ability to scavenge soil $\mathrm{N}$ by hybrid sunflower. Crop Improvement. 23(2): 247-252

Bhadoria, R.B.S., Tomar, R.A.S. and Sharma, M.K. 1997. Effect of phosphorus and Sulphur on yield and quality of c1usterbean (Cyamopistetragonoloba). Indian Journal of Agronomy, 42 (I): 131-134.

Chanda, N., S.S. Mondal, G. Arup and K. brahmachari. 2002. Effect of potassium and sulphur on mungbean in relation to growth, productivity and fertility buildup of soil. Interacademiciam. 6(3): 266- 271.

Joseph B, Verma SC, 1994. Response of rainfed chickpea to jalsakthi incorporation and $\mathrm{P}$ and $\mathrm{S}$ fertilization. Indian Journal of Agronomy, 39: 312-314

Panse, V.G., and Sukhatme, P.V. 1967. Statistical methods for research workers. ICAR, New Delhi, 220-40.

Ramamoorthy, K. Balasubramanian, A. and Arokiaraj, A.1997. Response of rainfedblackgram (Phaseolus mungo) to phosphorus and Sulphur nutrition in red laterite soils. Indian Journal of Agronomy.42 (1): 191-193.

Rao, C.S., Singh, K.K. and Ali, M. 2001. Sulphur: a key nutrient for higher pulse production. Fertilizer news.46(10): 5154

Rao, C.S., Singh, K.K. and Ali, M. 2001. Sulphur: a key nutrient for higher pulse production. Fertilizer news.46(10): 5154

Sharma, H.R. and Gupta, A.K. 2003. Effect of Sulphur on growth parameters and yield of some selected crops. Annals of Agricultural Research.24(1): 136- 138.

Sharma, H.R. and Gupta, A.K. 2003. Effect of sulphur on growth parameters and yield of some selected crops. Annals of Agricultural Research.24(1): 136- 138.

Shivran, A.C., Khangarot, S.S., Shivran, P.L. and Gora, D.R. 1996. Response of clusterbean (Cyamopsistetragonoloba (L.) Taub.) varieties to Sulphur and phosphorus. IndianJournal of Agronomy. 41 (2): 340-342.

Singh, Amar and Meena N.L. 2003. Effect of nitrogen and Sulphur on growth, attributes and seed yield of mustard (Brassica juncea) in eastern plain of Rajasthan. Indian Journal of Agronomy.49: 186-188.

Singh, Amar and Meena N.L. 2004. Effect of 
nitrogen and Sulphur on growth, attributes and seed yield of mustard (Brassica juncea) in eastern plain of Rajasthan. Indian Journal of Agronomy.49: 186-188.

Singh, H.N., Verma, R.N. and Singh., S. 2005. Performance of late sown chickpea (Cicer arietinum L) under different levels of row spacing, DAP and Sulphur in relation to growth and yield attributes, yield and economics. Farm Science Journal.14(1): 10-11.

Singh, H.N., Verma, R.N. and Singh., S. 2005. Performance of late sown chickpea (Cicerarietinum L) under different levels of row spacing, DAP and sulphur in relation to growth and yield attributes, yield and economics.
Farm Science Journal.14(1): 10-11.

Singh, M.V. 2001. Importance of sulphur in balanced fertilizer use in India. Fertilizer News.46(10): 13-18.

Singh, Y.P. and Aggarwal, R.L. 1998. Effect of sulphur sources and levels on yield, nutrient uptake and quality of blackgram (Phaseolus mungo). Indian Journal of Agronomy, 43(3), 448-452.

Singh, Y.P. and Aggarwal, R.L. 1998. Effect of sulphur sources and levels on yield, nutrient uptake and quality of blackgram (Phaseolus mungo). Indian Journal of Agronomy.43(3), 448-452.

Srinivasan, K. and Sankaran, N. 2001. Sulphur management in blackgram and its effect onyield and economics. Madras Agric. J.88 (10-12): 654-656.

\section{How to cite this article:}

Sri Laxmi, Ruby Patel, Sonam Singh, Babulal Choudhary, Rajendra Gadhwal, R. Meena and Singh. Y. V. 2020. Growth and Yield Response of Mungbean as Influenced by Sulphur and Boron Application. Int.J.Curr.Microbiol.App.Sci. 9(03): 2788-2794. doi: https://doi.org/10.20546/ijcmas.2020.903.320 